\title{
Experimental Study of Moving Truck Emissions on Inter-City National Road: A Case Study of Malino Main Road
}

\author{
Mukhtar Lutfie ${ }^{D},{ }^{1}$ Lawalenna Samang, ${ }^{2}$ Sakti A. Adisasmita, ${ }^{1}$ and Muhammad I. Ramli ${ }^{3}$ \\ ${ }^{1}$ Doctoral Student of Civil Engineering, Hasanuddin University, Makassar 90245, Indonesia \\ ${ }^{2}$ Professor of Civil Engineering, Hasanuddin University, Makassar 90245, Indonesia \\ ${ }^{3}$ Associate Professor of Civil Engineering, Hasanuddin University, Makassar 90245, Indonesia \\ Correspondence should be addressed to Mukhtar Lutfie; mukhtarluwuk09@gmail.com
}

Received 14 May 2018; Revised 24 August 2018; Accepted 9 September 2018; Published 8 October 2018

Academic Editor: Runcang Sun

Copyright (C) 2018 Mukhtar Lutfie et al. This is an open access article distributed under the Creative Commons Attribution License, which permits unrestricted use, distribution, and reproduction in any medium, provided the original work is properly cited.

\begin{abstract}
The research aimed to determine exhaust emission and speed of the truck when moving. Measurements were made using a mobile emission analyzer that absorbed emission from truck exhaust. Data collection was done by putting mobile emission analyzer on the right side of the vehicle which absorbs 5 emissions of approximately 5 minutes. The relationship of exhaust emission and speed uses the polynomial model of the average value of exhaust emission and speed. The reliability of mobile emission analyzer uses the multiplier factor to solve the data difference between mobile emission analyzer and Bosowa equipment. The results of research indicate emission of $\mathrm{CO}_{2}$, NOx, Smoke, $\mathrm{CO}$, and $\mathrm{HC}$ forming driving cycle pattern. This pattern shows the pattern follows parabola tendency. Emission on damaged road is higher than good road although the emission values are not much different. However, the value of emission of Smoke is relatively equal in both road conditions.
\end{abstract}

\section{Introduction}

The transport sector is one major cause of current environmental problems. Increased carbon dioxide, noise, air pollution, and physical and environmental disturbances are the negative impacts of transport. Globally, motor vehicles emit $14 \%$ of carbon dioxide-based fossil fuels, $50 \%-60 \%$ of carbon monoxide and hydrocarbons, and about $30 \%$ of nitrous oxide emissions [1]. The main causes of air pollution are due to motor vehicle exhaust due to poorly used fuel oil quality, traffic congestion, and traffic behavior on the road [25]. Emission is a problem that causes air pollution everywhere in both the surrounding environment on the road and the global environment that can affect the hotter air. It is one of the most basic problems. Each motor vehicle will exhaust emission that is large depending on the year of the vehicle and the type of fuel used. Vehicles for longer manufacturing years will exhaust more emissions than new; vehicles with gasoline will exhaust different types of emissions with diesel-fueled vehicles [6]. Emissions of vehicles containing heavy metals (lead, PB, etc.) if inhaled can interfere with human health.

Models of vehicle emissions prediction developed with the development of emission models as multiplying vehicle kilometer travel (VKT) and emission factor (EF). VKT is the multiplication of vehicle distance traveled (D) and traffic volume $(\mathrm{N})$; EF is the basic emission factor of each vehicle category. Variables that significantly affect vehicle emissions in urban areas with heterogeneous traffic situations are no longer the distance of vehicle travel (D) [7, 8]. Influential variables are travel time (TT) and actual vehicle driving cycle pattern [9]. The determination of driving cycle pattern on the highway has never been done in Indonesia. [4, 5] also conducted a study related to their respective driving cycle measurements in Bangkok, Thailand, and in Hanoi, Vietnam. Automotive emissions analysis is highly dependent on vehicle speed and acceleration. Speed and acceleration of the vehicle are a characteristic of the vehicle driving pattern $[4,5]$. The driving pattern of the vehicle in question is characteristic of the driving pattern on an urban highway determined on the basis of appropriate road trails and current traffic conditions. To date, no method has been found to choose the right route to analyze the actual driving pattern [4]. According to [10], the variable driving cycle patterns are idle situation, acceleration, deceleration, oncoming vehicle, and average speed of the vehicle. 


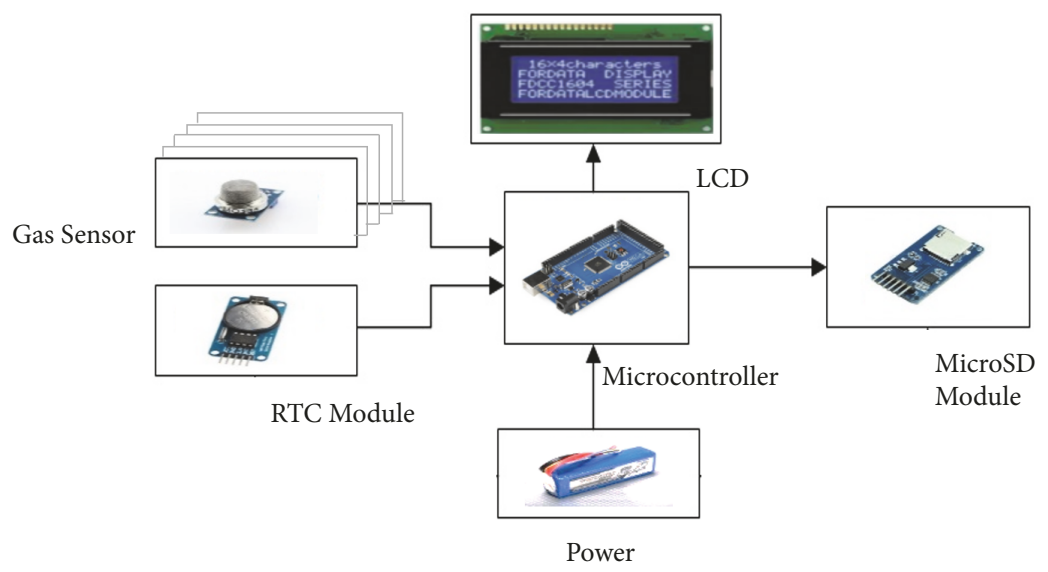

FIGURE 1: Work system diagram of mobile emission recording.

The largest composition of truck emissions on A.P. Pettarani road is $\mathrm{CO}_{2}$, but the percentage of vehicle type is small enough, $0.63 \%$ to $27.29 \%$, where its frequency distribution rate of the day is not similar for all arterial roads in Makassar city [11]. A study conducted on gas emissions generally found that the tendency that arises is the faster the vehicle speed, the greater the $\mathrm{CO}_{2}, \mathrm{NOx}$, Smoke, $\mathrm{CO}$, and $\mathrm{HC}$ released or this will increase with increasing vehicle speed. Thus, the relationship of emission with vehicle speed is a linear relationship [12]. Examined vehicle exhaust gas emissions, $\mathrm{CO}$, $\mathrm{NO}, \mathrm{NOx}$, and $\mathrm{CO}_{2}$, are measured at variations in the speed of moving vehicles $0,20,40$, and $60 \mathrm{~km} / \mathrm{h}$. The relationship of emission and vehicle speed uses a polynomial model. The result of emission measurement of the IVEM Model showed a low value of $\mathrm{CO}_{2}$, as well as other types of emissions [13]. The emission measurement results of the IVEM Model show a low $\mathrm{CO}_{2}$ value, as well as other types of emissions. Speed will also affect the amount of emissions issued by a vehicle. According to [6] emissions test in the United States, the higher speed used in a vehicle, the smaller amount of $\mathrm{HC}$ and $\mathrm{CO}$ emitted. This is inversely proportional to $\mathrm{NO}_{2}$, where the higher speed of motor vehicles use, the larger $\mathrm{NO}_{2}$ emitted. The measurements of running vehicle emissions starting by recording a pre-moving vehicle (zero speed) are described, but vehicle engine has been turned on [14].

The emission measurement equipment mounted on the diesel power plant valve is examined. The compounds consist of carbon monoxide $(\mathrm{CO})$, sulfur dioxide $\left(\mathrm{SO}_{2}\right)$, and nitrogen oxide $(\mathrm{NOx})$. The information about emission can be accessed using an online information system [15]. Percentage of trucks passing Malino Main Road is the Single Engkel 2.68\%, Double Engkel 84\%, Trintin 0\%, Tronton 12.64\%, and Trintin $0.26 \%$ [16]. The Bina Marga method has the final result in the analysis as the priority sequence and maintenance of road damage, while the PCI (Pavement Condition Index) method has the final result, namely, the pavement quality classification on the road segment. The form of maintenance that can be done is by giving an additional layer and compacting, the gap is filled with a mixture of asphalt and sand, and the pavement is dismantled and then overlaid with the same material [17].

Looking at the strategic issues and previous studies on vehicle emissions, then this research focused on developing mobile emission recording to assess emissions of trucks into good road and damaged road using driving cycle approach on Inter-City National Roads.

\section{Materials and Methods}

Method of research used is experimental method with quantitative approach. Research was conducted on Inter-City National Road of Malino Main, the segment of Gowa Malino Main Km. 6-8 road type 2/1 (1 lane 2 ways). Based on [16], the type of vehicle used for the sampling activity was determined where the volume of Double Engkel is the type of vehicle that dominates the trucks that pass Malino Main Road. Then in this research, the type of sample vehicle used is Double Engkel.

The survey was conducted by developing an Arduino Mega-based recording device, a device capable of recording the types of emissions such as $\mathrm{CO}_{2}$, NOx, Smoke, $\mathrm{CO}$, and $\mathrm{HC}$. The presence of flue gas detected by the sensor will make a difference in the resistance of the sensor so that it will affect the amount of output voltage from the sensor. The output from the sensor will be forwarded to the Arduino circuit, converted into digital data so that it can be read on the LCD, and the data is stored to the MicroSD. The work system diagram of moving truck emission measurement can be seen in Figure 1.

Emission recording of running truck was done by using mobile emission analyzer equipment made by Hasanuddin University. Vehicles operate on varying speeds starting from the beginning of the move at the first point until it stops at the second point. The vehicle exhaust gas is captured by a hose connected directly to the mobile emission analyzer. The activity of emission sampling is done by capturing the exhaust gases from the exhaust using an iron pipe. This gas pipeline is made in the right-angle shape and at one end is connected to a plastic hose to move flexibly. This hose is then connected to a tube containing $\mathrm{CO}_{2}, \mathrm{NOx}$, Smoke, $\mathrm{CO}$, and $\mathrm{HC}$ sensors. The end of the pipe that enters the exhaust is tied wires and rope so that the gas pipeline does not fall. Mobile emission analyzer is placed in the center of the vehicle beside the exhaust along with the battery.

Mobile emission analyzer is turned on and after heating for 2 minutes, the sample of vehicle is run with varying speed starting from the beginning of move until it stops. Determination of measurement duration is 5 minutes. Gas 


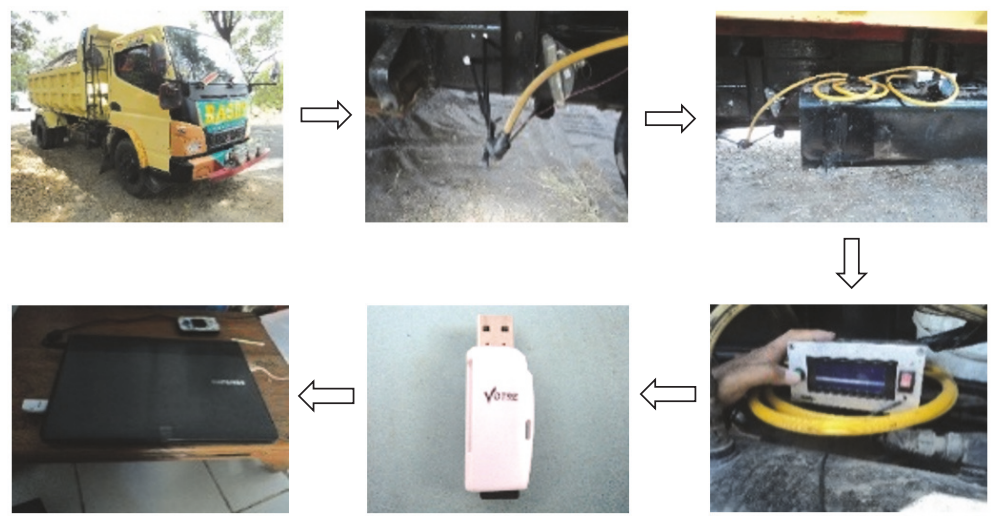

Figure 2: Stages of truck emissions measurement.
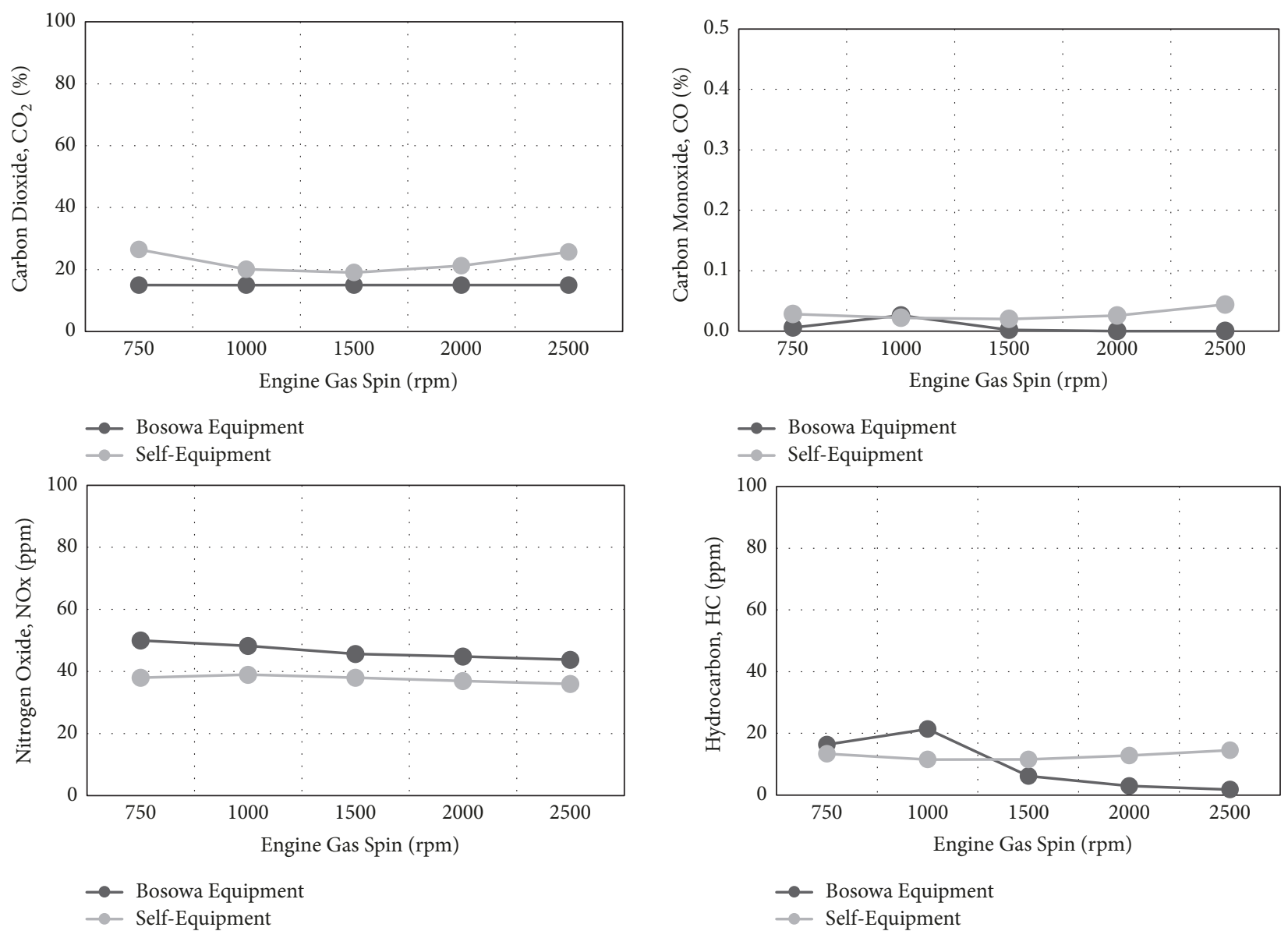

FIgUre 3: Comparison of emissions tests in PT. Bosowa Berlian Motor. (a) $\mathrm{CO}_{2}$. (b) CO. (c) NOx. (d) HC.

that comes from the exhaust is then flowed into a tube containing $\mathrm{CO}_{2}, \mathrm{NOx}$, Smoke, $\mathrm{CO}$, and $\mathrm{HC}$ sensors. Then the exhaust gas is read on the LCD screen of mobile emission analyzer. The data of gas compounds read by sensors is stored in MicroSD memory. The data can be copied to PC (Laptop, Notebook, Computer) using card reader, to then proceed with data processing. Exhaust emissions data and speed of truck observed on running vehicle are expressed in driving cycle patterns. Stages of emission measurements are shown in Figure 2.

\section{Results and Discussion}

3.1. Developing of Emission Mobile Recording. Testing of equipment validation is done by comparing between the mobile emission analyzer and Equif Tecnomotor on dieselfueled Colt Diesel vehicles with injection combustion system and Mirage model of gasoline-fueled Bosowa brand, 1200 CC, manufacturing year 2012, traveled distance $1218 \mathrm{~km}$ in PT. Bosowa Berlian International Motor and test results in emission correction factor. Comparison of emission tests is shown in Figure 3. 

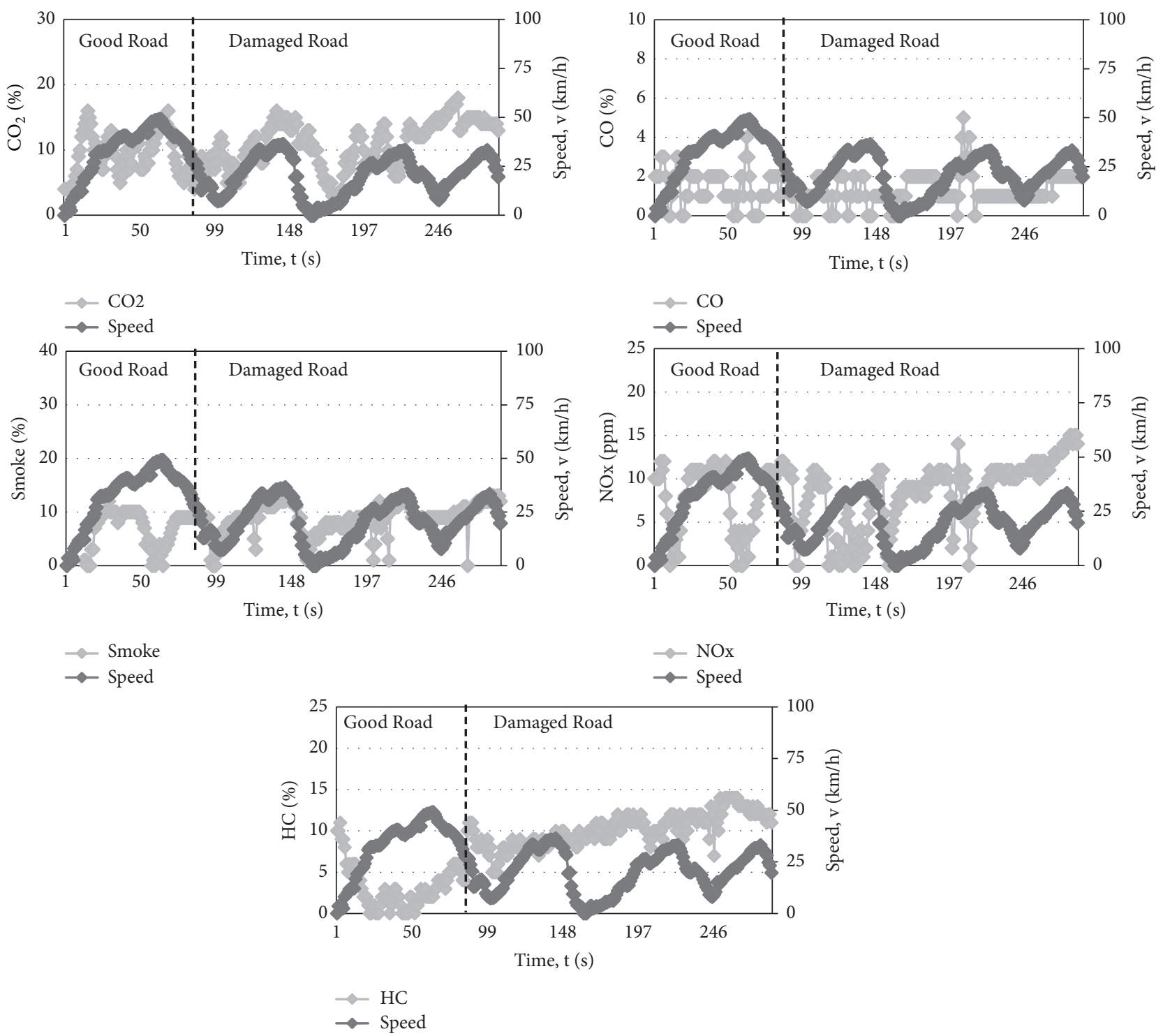

Figure 4: Spectrum of emission recording $\mathrm{CO}_{2}$, CO, Smoke, NOx, and HC.

Based on Figure 3 obtained the data difference from mobile emission analyzer and equif tachometer Bosowa where the average $\mathrm{CO}_{2}$ of Bosowa equipment is $15.00 \%$ and the self-equipment is $22.53 \%$, then to solve the data difference of Bosowa and self-equipment needed correction factor 0.666; average $\mathrm{CO}$ of Bosowa equipment is $0.007 \%$ and self-equipment is $0.028 \%$, then to solve the data differs from the self-equipment and Bosowa needed correction factor 0.243; average value of NOx of Bosowa is $46.5 \mathrm{ppm}$ and self-equipment is $37,6 \mathrm{ppm}$, then to solve the data difference from the self-equipment and Bosowa needed correction factor 1.236; and the average $\mathrm{HC}$ of Bosowa equipment is $9.76 \%$ and the self-equipment is $12.773 \%$, then to solve the data difference from the self-equipment and Bosowa needed a multiplier factor 0.764 .
3.2. Spectrum of Mobile Emission Recording on Truck. Assessment surfaces road damaged condition was identified visually using Bina Marga method (1990) and PCI method (1994). Exhaust emission patterns of $\mathrm{CO}_{2}, \mathrm{CO}$, Smoke, $\mathrm{NOx}$, and $\mathrm{HC}$ on running truck condition in good and damaged road are shown Figure 4, with the truck running in Poros Malino street on good road condition until 85 seconds and speed $0 \mathrm{~km} / \mathrm{h}$ to $49,1 \mathrm{~km} / \mathrm{h}$, emission of $\mathrm{CO}_{2} 4 \%-16 \%$, CO 0\%-3\%, Smoke 0\%-13\%, NOx 0\%-12\%, HC 0\%-11\%, and with the truck running on damaged road conditions until 197 seconds and speed $0 \mathrm{~km} / \mathrm{h}$ to $35,8 \mathrm{~km} / \mathrm{h}$, emission of $\mathrm{CO}_{2} 3 \%-18 \%$, CO $0 \%-5 \%$, Smoke $0 \%-13 \%$, NOx 0\%-15\%, and HC 5\%-14\%. From the above data can be seen the relationship between exhaust emissions and speed in damaged road conditions with higher $\mathrm{CO}_{2}, \mathrm{CO}, \mathrm{NOx}$, and $\mathrm{HC}$ values than good road conditions although the 

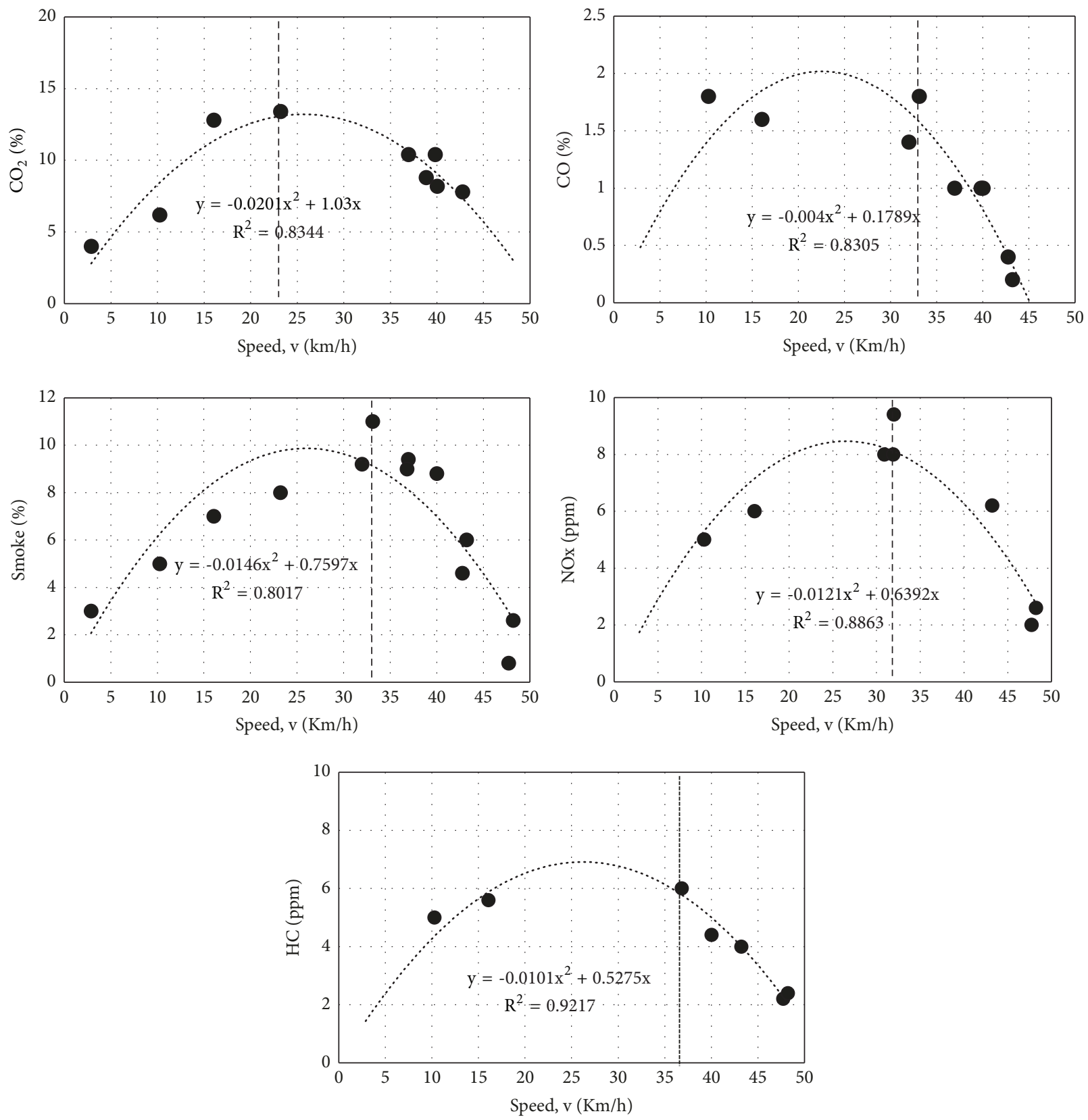

FIGURE 5: Exhaust emission driving cycle pattern on good road conditions.

emission value is not much different. However, value of emission Smoke is relatively equal in both road conditions.

\subsection{Exhaust Emission Driving Cycle Pattern of Truck}

3.3.1. Exhaust Emission Driving Cycle Pattern of Trucks on Good Road Conditions. Exhaust emission driving cycle pattern of truck on running condition into good road is shown Figure 5. Driving cycle pattern depicts parabolic curve, where emission values to show go up maximal at a certain speed of $\mathrm{CO}_{2} 23,22 \mathrm{Km} / \mathrm{h}$, CO 33,12 Km/h, Smoke $33,12 \mathrm{Km} / \mathrm{h}$, NOx $31,98 \mathrm{Km} / \mathrm{h}$, and HC $36,82 \mathrm{Km} / \mathrm{h}$.
3.3.2. Exhaust Emission Driving Cycle Pattern of Truck on Damaged Road Conditions. Exhaust emission driving cycle pattern of truck $\left(\mathrm{CO}_{2}, \mathrm{CO}\right.$, Smoke, $\mathrm{NOx}$, and $\left.\mathrm{HC}\right)$ on running condition into damaged road is shown Figure 6. Driving cycle pattern depicts parabolic curve, where emission values go up maximal at a certain speed of $\mathrm{CO}_{2} 19,16 \mathrm{Km} / \mathrm{h}, \mathrm{CO} 27,32$ $\mathrm{Km} / \mathrm{h}$, Smoke $25,9 \mathrm{Km} / \mathrm{h}$, NOx 19,7 Km/h, and HC 27,32 $\mathrm{Km} / \mathrm{h}$.

Looking at Figures 5 and 6 trucks loaded on good and damaged roads show that the magnitude of $\mathrm{CO}_{2}, \mathrm{CO}$, and Smoke emissions is not significantly different, $\approx 1 \%$, NOx and $\mathrm{HC}$ emission of good and damaged roads. It appears that the emission difference is $\approx 4 \mathrm{ppm}$. 

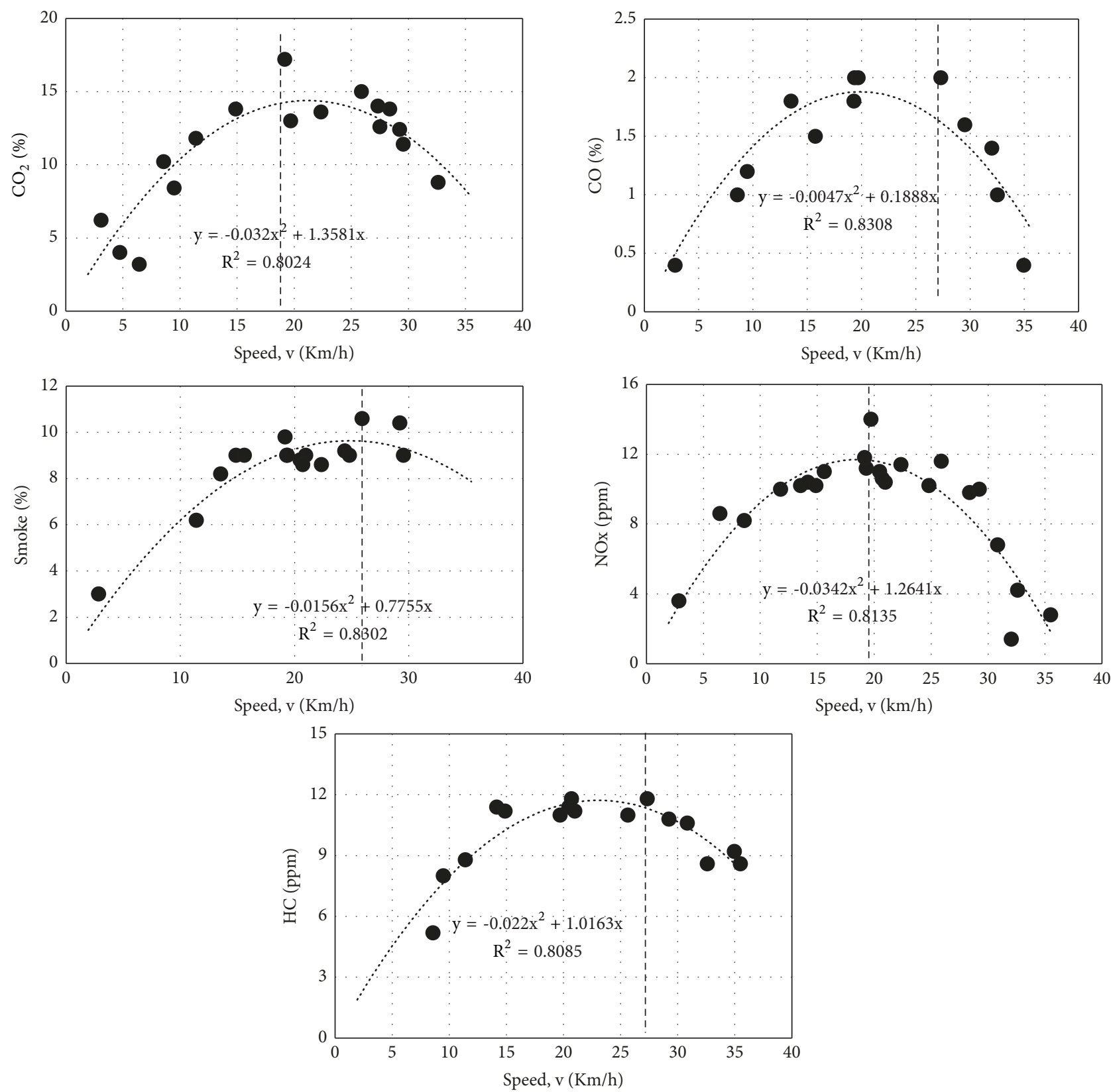

FIGURE 6: Exhaust emission driving cycle pattern of truck on damaged road conditions.

3.4. Optimum Speed of Exhaust Emission Driving Cycle Pattern. Figure 7 represents the optimum speed driving cycle pattern of truck on running condition into good road and damaged road. Optimum speeds value in damaged road is $\mathrm{CO}_{2} 19,16 \mathrm{Km} / \mathrm{h}$, CO 27,32 Km/h, Smoke $35,48 \mathrm{Km} / \mathrm{h}$, NOx $19,7 \mathrm{Km} / \mathrm{h}$, and $\mathrm{HC} 27,32 \mathrm{Km} / \mathrm{h}$ and optimum speeds value in good road is $\mathrm{CO}_{2} 23,22 \mathrm{Km} / \mathrm{h}$, CO $33,12 \mathrm{Km} / \mathrm{h}$, Smoke 33,12 $\mathrm{Km} / \mathrm{h}$, NOx $31,98 \mathrm{Km} / \mathrm{h}$, and HC $36,82 \mathrm{Km} / \mathrm{h}$.

\section{Conclusions}

The road condition was identified as good or damaged by using the criteria of Bina Marga and PCI. The reliability of mobile emission analyzer uses the multiplier factor to solve the data difference between mobile emission analyzer and Bosowa equipment. The result of emission analysis truck with driving cycle pattern shows the pattern follows parabolic tendency. Emission values of $\mathrm{CO}_{2}, \mathrm{CO}, \mathrm{NOx}$, and $\mathrm{HC}$ in damaged road are higher than good road even though the emission values are not much different. However, value of emission of Smoke is relatively the same in both road conditions.

\section{Data Availability}

The data used to support the findings of this study are available from the corresponding author upon request. 

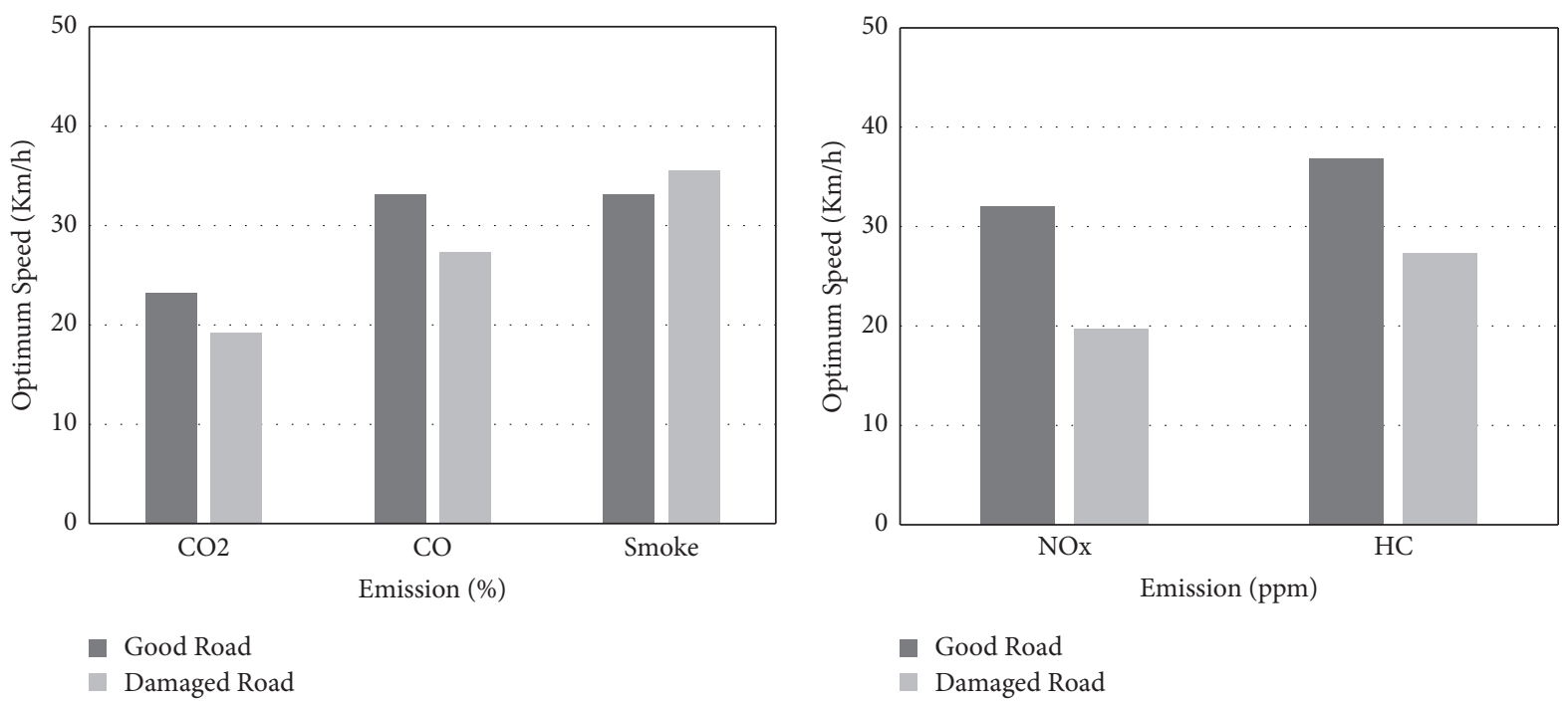

FIGURE 7: Optimum speed driving cycle pattern.

\section{Conflicts of Interest}

The authors declare that there is no conflict of interest in the publication of this paper.

\section{Acknowledgments}

We would like to express our thanks to all parties/institutions that support this research. In particular appreciation is given to the Coordinator of Private Higher Education Region IX in Makassar and Muhammadiyah University, Luwuk, for financing support in this study. We also express appreciation for assembly of this emission measurement device that materialized on good collaboration between Ujung Pandang Polytechnic and Faculty of Engineering, Hasanuddin University, Makassar.

\section{References}

[1] K. P. Hwang, " $\mathrm{CO}_{2}$ Emission: status, reduction policy and management strategy of taiwans transportation sector," Proceeding of the Eastern Asia Society for Transportation Studies, vol. 6, 2007.

[2] M. Ilyas, "Mengatasi Emisi melalui Perencanaan Sistem Transportasi Perkotaan And Kebijakan Pengendaliannya," Sekolah Pascasarjana IPB, 2004.

[3] O. Z. Tamin, Perencanaan and Pemodelan Transportasi: Contoh Soal and Aplikasi. Edisi ke-2. Bandung: Penerbit ITB, 2007.

[4] T. Nutramon and C. Supachart, "Influence of driving cycles on exhaust emissions and fuel consumption of gasoline passenger car in Bangkok," Journal of Environmental Sciences, vol. 21, no. 5, pp. 604-611, 2009.

[5] H. Y. Tong, H. D. Tung, W. T. Hung, and H. V. Nguyen, "Development of driving cycles for motorcycles and light-duty vehicles in Vietnam," Atmospheric Environment, vol. 45, no. 29, pp. 5191-5199, 2011.

[6] K. E. Morlok, Pengantar Teknik and Perencanaan Transportasi, Jakarta, Erlangga, Indonesia, 1991.
[7] T. J. Lyons, J. R. Kenworthy, C. Moy, and F. dos Santos, "An international urban air pollution model for the transportation sector," Transportation Research Part D, vol. 8, no. 3, pp. 159-167, 2003.

[8] N. Kalandiyur, "Estimating Vehicle Emissions in Transportation Planning Incorporating the Effect of Network Characteristics on Driving Patterns," in Transportation Science, R. Jayakrishnan and M. G. McNally, Eds., p. 189, 2007.

[9] S. H. Aly, M. I. Ramli, and T. Sumi, "Driving Cycle of Passenger on Heterogeneous Traffic Situation: Case Study on An Urban Road in Makassar, Indonesia," in Proceedings of the 8th International Symposium on Lowland Technology (ISLT), Bali, Indonesia, 2012.

[10] K. S. Nesamani and K. P. Subramanian, "Development of a driving cycle for intra-city buses in Chennai, India," Atmospheric Environment, vol. 45, no. 31, pp. 5469-5476, 2011.

[11] M. Lutfie, L. Samang, A. Sakti, and I. Ramli, "Composition Analysis Of Emission Truck On Urban Road Network In Makassar," in Proceedings of the 2nd Makassar International Conference on Civil Engineering (Gowa), vol. 2, pp. 355-362, Civil Engineering Department Hasanuddin University, Makassar, Indonesia, 2015.

[12] M. Lutfie, L. Samang, S. A. Adisasmita, and M. I. Ramli, "Speed Correlation and Emission of Truck Vehicles on Dynamic Conditions," in Proceedings of the 4th International Conference on Civil and Environmental Engineering for Sustainability, vol. 140, IOP Conference Series: Earth and Environmental Science, Langkawi, Malaysia, 2018.

[13] S. H. Aly and M. I. Ramli, "Running vehicle emission factors of passenger cars in makassar indonesia," Proceedings of the Eastern Asia Society for Transportation Studies, vol. 9, pp. 307315, 2013.

[14] Aly. Sumarni Hamid, Emisi Transportasi, Kuantitas Emisi Berdasarkan Marni Model, Jakarta, Indonesia, 2015, Plus+.

[15] S. Ansar, "Web-Based Gas Emission Level Monitoring of Diesel Power Plant using Multi-Sensors International," Journal of Engineering and Innovative Technology (IJEIT), vol. 3, pp. 21-25, 2013. 
[16] M. Lutfie, L. Samang, A. Sakti, and I. Ramli, Estimasi Emisi Engkel Ganda Berbasis Pengukuran Dinamis Pada Jalan Poros Malino Gowa. Seminar Nasional Transportasi, Infrastuktur, and Lingkungan 2016 (SENTRAL 2016) Graha Pena, Universitas Fajar, Makassar, Indonesia, 2016.

[17] P. Bayu, Evaluasi Tingkat Kerusakan Jalan Sebagai Dasar Penentuan Perbaikan Jalan Menggunakan Metode Bina Marga and Metode PCI (Pavement Condition Index), Universitas Gajah Mada, 2014. 


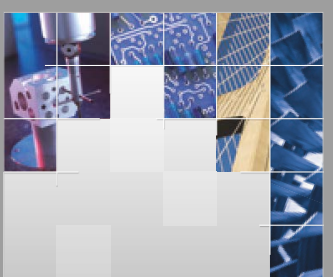

\section{Enfincering}
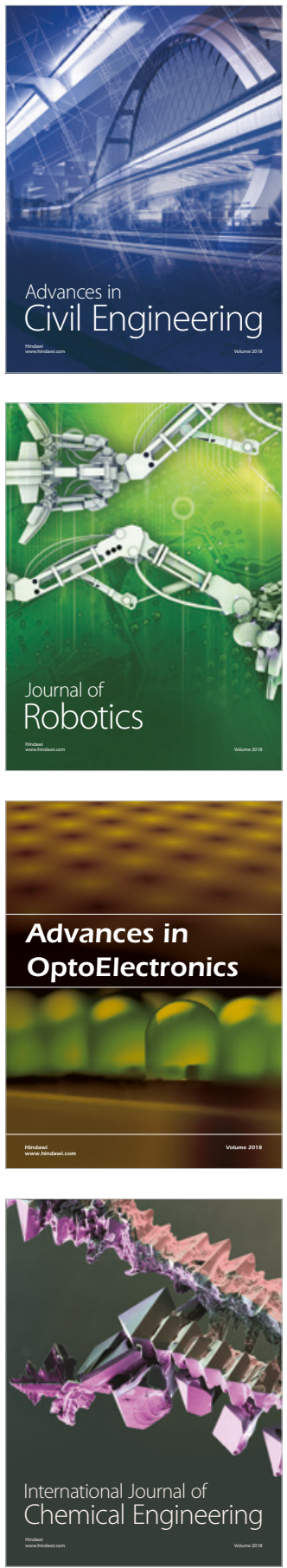

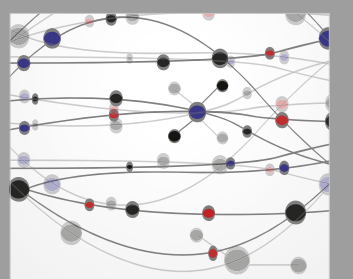

\section{Rotating \\ Machinery}

The Scientific World Journal

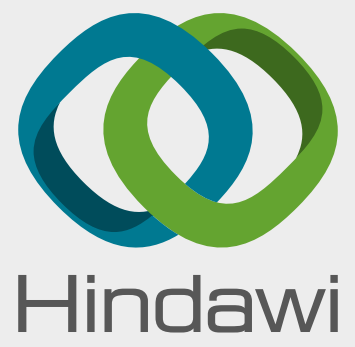

Submit your manuscripts at

www.hindawi.com
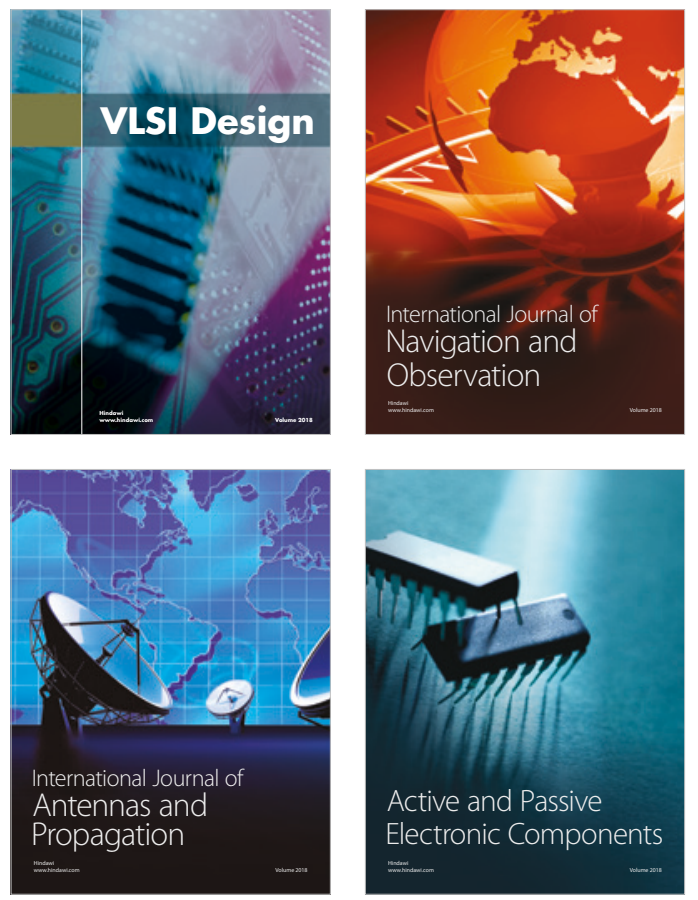
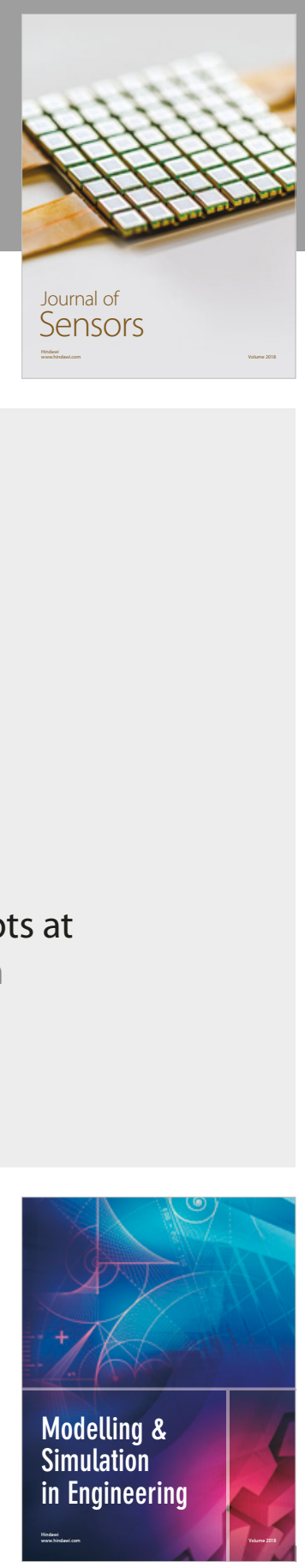

\section{Advances \\ Multimedia}
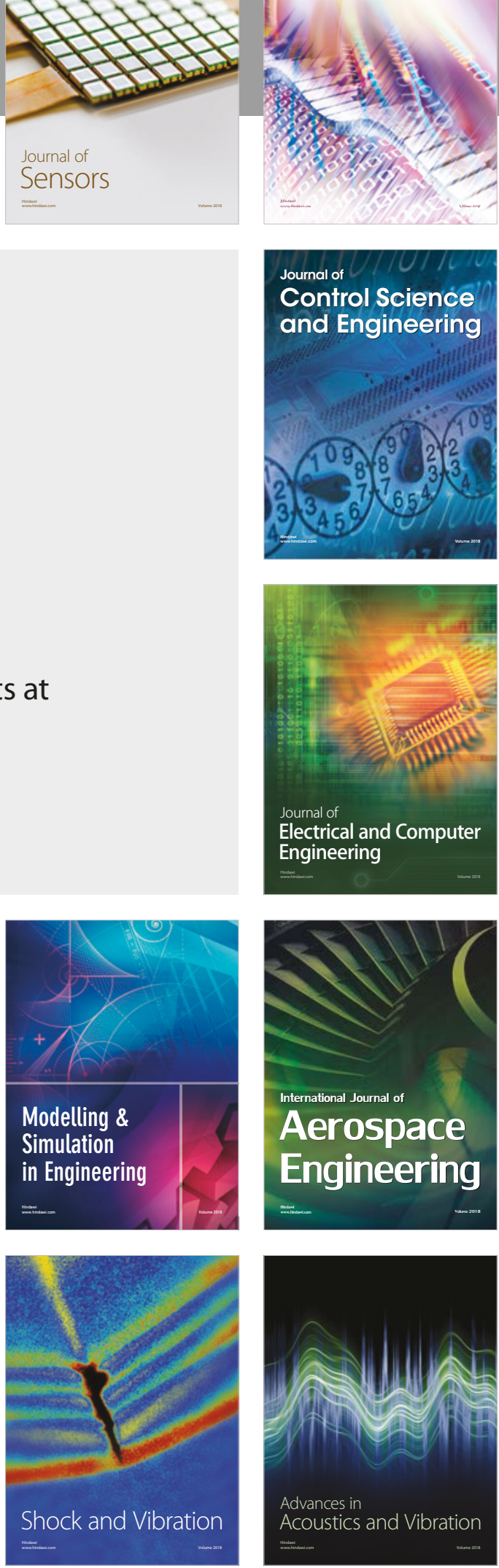